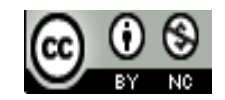

Journal of Education, Teaching, and Learning is licensed under

A Creative Commons Attribution-Non Commercial 4.0 International License.

\title{
THE DeVelopMent OF E-LEARNING TEACHING MATERIAL BASED ON EDMODO ON BASIC COMPETENCIES OF NATIONAL INTEGRATION AT Class X OF SENIOR High SCHOOL
}

\author{
Linda Solehana ${ }^{1)}$, Asrori $^{2)}$, Andy Usman ${ }^{3)}$ \\ ${ }^{1)}$ Universitas Tanjungpura, Pontianak, Indonesia \\ E-mail: lindasolehana@gmail.com \\ ${ }^{2)}$ Universitas Tanjungpura, Pontianak, Indonesia \\ E-mail:asroriuntan@yahoo.com \\ ${ }^{3)}$ Universitas Tanjungpura, Pontianak, Indonesia \\ E-mail: andyusman567@gmail.com
}

\begin{abstract}
This research aims to determine (1) the design of E-learning teaching materials, (2) steps for using Edmodobased learning materials (3) student learning behaviour in learning using Edmodo-based E-learning. The development model used is a procedural model adapted from the instructional design development model according to Dick \& Carey while the development research model used is in accordance with Borg \& Gall. The instrument used was in the form of a questionnaire instrument, interview guidelines and observation guidelines (observations). The data analysis used in this study is qualitative descriptive statistics. Noting the validation of experts and the results of trials in the field, it can be concluded that: (1) Edmodo-based E-learning teaching materials on Basic Competence (KD) of National Integration are appropriate to use for Class X (Grade 10 ${ }^{\text {th }}$ ) SMA PPKn subjects; (2) Clarity of instructions for using E-learning teaching materials is considered good; (3) Changes in student learning behaviour are students who look very enthusiastic about learning by using E-learning teaching materials; (4) Edmodo-based E-learning materials are considered effective in achieving the learning objectives of the PPKn; (5) Edmodo-based E-learning teaching materials have a high time and place efficiency with regard to the limitations of available teaching materials; (6) Edmodo-based E-learning teaching material is a strategy for delivering messages that have high competitiveness. For research on the development of Elearning teaching materials based on Edmodo that will come to be more refined and better in order to support the smooth learning process.
\end{abstract}

Keywords: Teaching Materials; E-Learning; Edmodo;National Integration

\section{INTRODUCTION}

The teacher has the right to design and determine the learning process in the classroom, determine indicators of achievement of competencies, learning objectives, main points, approaches, models and methods, assessment of learning adapted to the ability of the teacher, characteristics of students, facilities and infrastructure, learning resources and available time allocation. However, the learning process must be in accordance with the 2013 curriculum (Tolib \& Nuryadi, 2017: 50).

The opinions of Tolib and Nuryadi above, it can be concluded that the teacher is given the freedom to design and determine the learning process in the class. including in making teaching materials.

In making instructional materials, there are not many teachers in school PPKn learning using computer assisted learning media/CAI in line with what was stated by Solihatin (2014: 190), namely:

Although the media is diverse, but in reality there are not many types of media commonly used by teachers in schools. Some of the most familiar and almost utilizing media are printed media (books) and blackboards. In addition there are also many schools that have used other types of media such as images, models, overhead projectors (OHPs) and real objects. While other media such as audio cassettes, videos, VCDs, slides (film frames), computer learning programs are 
still rarely used even though they are already familiar to most teachers.

In the PPKn syllabus of SMA/MA/SMK/MAK Curriculum (Kemendikbud, 2017: 12) it is stated that PPKn teachers must be equipped with the ability to use IT in using or developing LKS and writing enrichment books. In addition, with the opening of free and open source education resources both nationally and globally, PPKn teachers must try to use the internet network in learning by developing network-based learning (online learning). Thus, PPKn learning becomes a blended learning process.

From the two opinions above, it can be concluded that the curriculum has become a demand, PPKn teachers are able to develop teaching materials by utilizing the internet network. Teaching materials that are in accordance with the demands of the curriculum are E-learning teaching materials. Teaching materials E-learning is one alternative to overcome problems in learning PPKn.

From the results of interviews with PPK Class X teachers, Social Sciences Department encountered problems in PPKn learning in High School Class X, including: first, the low value of class $\mathrm{X}$ student learning outcomes at $\mathrm{KD}$ of national integration, only $62,5 \%$ or 20 students completed 32 students. While as many as 12 students or $37.5 \%$ of students were not completed with KKM 75. The second was the limited number of textbooks in the school library. The three teachers are more likely to buy other people's artificial teaching materials such as student worksheets (LKS) because they are cheap so that all students can have them. The four speeds and learning styles of students are different, the five time constraints available in classroom learning. The six lessons are still teacher-centered. The seven teachers of PPKn class X of SMAN 8 Pontianak stated that they needed teaching materials that could be owned by all students, were easy to carry everywhere and could be accessed at any time.

Whereas based on observations of researchers who are also teachers of PPKn class X Science Department at SMAN 8 Pontianak, in pre-observation there were several problems found in the learning of National Integration $\mathrm{KD}$, including the first, several students often seen using mobile phones when following the learning process . Both students mostly respond to $\mathrm{KD}$ of national integration seen from the noisy class atmosphere, student concentration is lacking, most students are passive when participating in discussions only certain students are actively asking, answering, responding or expressing their ideas. While the advantages that I encountered during the PPKn lesson were firstly that the internet network at SMAN 8 Pontianak was good. Secondly, almost all students have mobile phones that are brought to school and in SMAN 8 Pontianak there is no prohibition on using HP in learning.

To strengthen the pre-observation carried out on January 9, 2018, the researcher conducted a questionnaire on 33 students of class $\mathrm{X}$ in SMA Negeri 8 Pontianak. The distribution of the questionnaire was conducted hetrogenally to find out the problems in PPKn learning. From the questionnaire distribution, it reinforced the results of observations of researchers that there were problems in $\mathrm{KD}$ of national integration learning, namely, first students did not have textbooks. Both teachers used the lecture method so that PPKn learning became boring. Third, students are not active in class discussions. Fourth, only a small number of students concentrate on listening to the teacher's explanation. Fifth, student learning is very low, only three people complete the national integration KD.

To overcome weaknesses and strengths in learning class $\mathrm{X}$ PPKn in high school, researchers who are also PPKn subject teachers chose to develop E-learning Teaching Materials Based on Edmodo on KD Class X National Integration High School.

\section{Methodology}

The research approach taken in this study is a qualitative approach. This means that the natural order is a direct source of data and the perpetrator of the research itself is a key instrument (Asrori and Ali, 2014: 122).

Qualitative research does not attempt to find evidence for testing hypotheses derived from theory, but research actors go to the field to collect various evidence through reviewing phenomena and based on the results of the study formulated theories (Asrori and Ali, 2014: 123). So that the objective in qualitative research is to describe the empirical reality behind phenomena in depth, detail and completeness. Therefore the use of a qualitative approach in this study is to match empirical reality with the prevailing theory using descriptive methods.

The development model used is a procedural model adapted from the instructional design development model according to Dick \& Carey while the development research model used is according to Borg \& Gall.

The test subjects were students of class X MIPA 1, SMAN 8 Pontianak. The total number of subjects was 41 people, with details of three individual pilot students, six small group trial students, and 32 large group trial students.

In this development research, the instruments used were questionnaire instruments, interview guidelines and observation guidelines (observations). The data analysis used in this study is qualitative descriptive statistics.

\section{RESULTS AND DISCUSSION}

\section{A. Results}

\section{Initial Trial Test}

The initial trial was intended to anticipate errors in users (students). Material experts provide information about the quality of the contents of E-learning teaching materials that are being developed. Media experts provide information about the quality of Edmodo-based learning media design to develop E-learning teaching materials in the National Class $\mathrm{X}$ High School Integration KD. Learning design experts provide information about the quality of Dick \& Carey's learning design with the Blended learning learning model that researchers conducted to develop Edmodo-based Elearning teaching materials. 
From the data of material experts, media experts and learning design experts are taken into consideration to make improvements to E-learning teaching material products. Evaluation of E-learning teaching materials was conducted by two material lecturers namely Dr. Sulistyarini, M.Sc and Thomy Sastra Atmaja who are lecturers of PPKn FKIP UNTAN. While media experts are Dr. Herry Sujaini, ST., M.T and Dr. Warneri, M.Sc who is a Masters in Education Technology FKIP UNTAN. While for learning design experts, Prof. Dr. H. Aunurrahman, M.Pd and Dr. Fadillah, M.Pd who is a S2 lecturer in Educational Technology FKIP UNTAN.

The composition and initial composition of E-learning teaching materials developed consist of (1) cover page, (2) introduction, (3) disclaimer, (4) table of contents (5) National Integration KD concept map, (6) competency standards and Basic competencies, (7) Learning Objectives (8) Material, has the following composition: Introduction, Readings, material pictures, Independent activities, Group activities, (9) Summary, (10) Competency Tests, (11) Glossary, ( 12) References.

Based on the initial arrangement, further input from the material expert, Dr. Sulistyarini, M.Sc who gave 1 response and Thomy Atmaja Literature. who gave the response 2 The review of the material expert can be seen in Table I.

TABLE I

REVIEW RESULTS OF MATERIAL EXPERTS

\begin{tabular}{|c|c|c|c|}
\hline \multirow{2}{*}{ No } & \multirow{2}{*}{ Topic } & \multicolumn{2}{|c|}{ Responses } \\
\hline & & 1 & 2 \\
\hline 1 & $\begin{array}{l}\text { Compatibility of } \\
\text { topics with } \\
\text { material }\end{array}$ & Very good & Very good \\
\hline 2 & Material Extent & Very good & Very good \\
\hline 3 & $\begin{array}{l}\text { Material } \\
\text { integration }\end{array}$ & Good & Very good \\
\hline 4 & $\begin{array}{l}\text { Clarity of material } \\
\text { presentation }\end{array}$ & Good & Very good \\
\hline 5 & $\begin{array}{l}\text { Ease to understand } \\
\text { material }\end{array}$ & Very good & Good \\
\hline 6 & $\begin{array}{l}\text { The accuracy of } \\
\text { the examples } \\
\text { clarifies the } \\
\text { content }\end{array}$ & Very good & Very good \\
\hline 7 & $\begin{array}{l}\text { Suitability of the } \\
\text { image with the } \\
\text { contents of the } \\
\text { material }\end{array}$ & Very good & Very good \\
\hline 8 & $\begin{array}{l}\text { Use of language in } \\
\text { explaining } \\
\text { material }\end{array}$ & Good & Good \\
\hline 9 & $\begin{array}{l}\text { Material balance } \\
\text { with practice }\end{array}$ & Very good & Very good \\
\hline 10 & $\begin{array}{l}\text { The questions that } \\
\text { were presented }\end{array}$ & Good & Very good \\
\hline
\end{tabular}

The results of the review of material experts were reviewed as a basis for revising E-learning teaching materials. To assess the accuracy of the media design design used in developing E-learning teaching materials, a review of media experts was requested. The results of the review of media experts are explained in Table II.

TABLE II

REVIEW RESULTS OF MEDIA EXPERTS

\begin{tabular}{|c|c|c|c|}
\hline \multirow{2}{*}{ No } & \multirow{2}{*}{ Topic } & \multicolumn{2}{|c|}{ Responses } \\
\hline & & 1 & 2 \\
\hline 1 & $\begin{array}{l}\text { Ease of access } \\
\text { Edmodo/Link }\end{array}$ & Good & Very good \\
\hline 2 & $\begin{array}{l}\text { Clarity Instructions } \\
\text { for using Edmodo }\end{array}$ & Good & Very good \\
\hline 3 & $\begin{array}{l}\text { Ease of using the } \\
\text { navigation menu }\end{array}$ & Good & Very good \\
\hline 4 & $\begin{array}{l}\text { The presentation is } \\
\text { interesting }\end{array}$ & Good & Good \\
\hline 5 & Color selection & Good & Good \\
\hline 6 & $\begin{array}{l}\text { Typography (type } \\
\text { and arrangement of } \\
\text { letters) }\end{array}$ & Good & Good \\
\hline 7 & Layout & Very good & Good \\
\hline 8 & Interesting image & Good & Good \\
\hline 9 & $\begin{array}{l}\text { Ease of use of } \\
\text { teaching materials }\end{array}$ & Good & Very good \\
\hline
\end{tabular}

Next to assess the accuracy of learning design was asked to review the learning design expert. Learning design experts assess the accuracy of the Dick and Carey design and the use of the Blended learning learning model. The results of the validation of learning design experts are explained in Table III.

\section{Product Revision}

After being validated by experts, the initial product revision was carried out so that the Edmodo-based E-learning materials developed were worthy of being tested. Evaluation, criticism, and suggestions from material experts, media experts and learning design experts are used as the basis for revising PPKn teaching materials products.

a) Material Revision

In accordance with the contents of the evaluation sheet and the responses of the material content material experts are very good so that teaching materials can be used, but there are some things that need to be addressed including avoiding the use of non-standard words and there are some sentences that must be corrected so that students easily understand teaching materials.

b) Media Revision

After evaluating with media experts, the average media for the development of E-learning teaching materials is good, there are only a few things that need to be done, namely improving the color quality and sharpness of the guide for using E-learning teaching materials.

c) Revision of Learning Design

After evaluating with learning design experts the results are all descriptions and points of good statements and in accordance with the aspects to be studied. Input from learning design experts is that the implementation of teaching materials is expected to pay attention to the dynamics in the class that occur during learning. 
TABLE III

LEARNING DESIGN REVIEW RESULTS BY LEARNING DESIGN EXPERTS

\begin{tabular}{|c|c|c|c|}
\hline \multirow{2}{*}{ No } & \multirow{2}{*}{ Topic } & \multicolumn{2}{|c|}{ Responses } \\
\hline & & 1 & 2 \\
\hline 1 & $\begin{array}{l}\text { Encouraging students' gratitude } \\
\text { towards God Almighty (KI-1) }\end{array}$ & Very good & Very good \\
\hline 2 & $\begin{array}{l}\text { Encouraging the development } \\
\text { of values that form a } \\
\text { commitment to national } \\
\text { integration (KI-2) }\end{array}$ & Very good & Very good \\
\hline 3 & $\begin{array}{l}\text { Develop conceptual and } \\
\text { procedural abilities in national } \\
\text { integration material in } \\
\text { accordance with student } \\
\text { interests (KI-3) }\end{array}$ & Very good & Very good \\
\hline 4 & $\begin{array}{l}\text { Stimulating students' abilities } \\
\text { in } 5 \mathrm{M} \text { (observing, managing, } \\
\text { collecting data, associating and } \\
\text { communicating (KI-4) }\end{array}$ & Very good & Very good \\
\hline 5 & $\begin{array}{l}\text { Encourage students to think } \\
\text { critically }\end{array}$ & Good & Good \\
\hline 6 & Develop literacy activities. & Good & Good \\
\hline 7 & $\begin{array}{l}\text { Encourage the development of } \\
\text { high order thinking skills } \\
\text { (HOT) }\end{array}$ & Good & Good \\
\hline 8 & $\begin{array}{l}\text { Centered on student learning } \\
\text { activities }\end{array}$ & Very good & Good \\
\hline 9 & $\begin{array}{l}\text { Encouraging the development } \\
\text { of } 21 \text { st century skills }\end{array}$ & Very good & Good \\
\hline 10 & $\begin{array}{l}\text { Conformity with the level of } \\
\text { social-emotional development } \\
\text { of students }\end{array}$ & Good & Good \\
\hline 11 & $\begin{array}{l}\text { Conformity between } \\
\text { approaches, learning models } \\
\text { and learning methods }\end{array}$ & Very good & Good \\
\hline 12 & $\begin{array}{l}\text { Conformity between media and } \\
\text { learning tools }\end{array}$ & Very good & Good \\
\hline 13 & $\begin{array}{l}\text { Understanding of Blended } \\
\text { learning syntax (using E- } \\
\text { learning teaching materials for } \\
\text { Blended learning) }\end{array}$ & Very good & Good \\
\hline
\end{tabular}

\section{Results of Testing on Phase II}

During the development of phase II three tests were conducted, one-on-one trials, small group trials, and large group trials.

\section{a). Test one one}

One trial was carried out with 3 students. In this one-onone trial students were asked to follow and study the entire contents of the national integration KD. After the national integration KD is studied, students are asked to provide input on Edmodo-based e-leaning teaching materials that have been studied. Questionnaire sheets are used to assess the quality of display of E-learning teaching materials.

The one-on-one evaluation of the display of instructional materials has an average score of 3.7. Because the value of 3.7 is above or is on the right side of the median linkert scale (2.5), the aspects of the quality of display of E-learning teaching materials in this research and development are good.

After evaluating the quality of display of E-learning teaching materials, the three students were still asked to assess the quality of presentation of teaching materials, the results of which were obtained an average score of 3.7 which meant the quality of presentation of teaching materials in research and development was good.

\section{b) Small Group Trial}

Before testing the teaching material, students are given a pretest first. The results of the pretest values are used to take samples in small classes. Small group trials of E-learning teaching materials were conducted to identify shortcomings of teaching materials after one one trial.

The results of student assessment for the quality of display of teaching materials are good with an average score of 3.7. The average score of 3.7 is to the right of the median linkert scale score (2.5.)

The results of student assessment for the quality of display of teaching materials are good with an average score of 3.7. The average score of 3.7 is to the right of the median linkert scale score (2.5.)

\section{c) Large Group Trial}

In this field trial students were asked to assess the display quality and quality of product presentation, product effectiveness by looking at the speed for student work, the efficiency of time spent and the attractiveness of teaching materials.

The following data are presented in a row and data analysis in stage 3 field trials.

a. Data and analysis on large group

1) Data and analysis on large group trials

Based on the assessment of students in a large group trial on the quality of display of E-learning teaching materials, the average score was 3.8. The score of 3.8 is to the right of the median linkert scale (2.5), meaning that on average the quality aspects of the display of E-learning teaching materials are considered good. For the assessment of students in the field trials on the quality of presentation of E-learning teaching materials, the average score was 3.7. A score of 3.7 is on the right of the median likers scale (2.5), meaning that on average the quality aspects of the presentation of E-learning teaching materials are considered good.

2) Value data for pre test and post test

To find out the effectiveness and ineffectiveness of field trials is to compare the initial test and the final test. Knowledge of this level of effectiveness is not to decide whether to use or not to use the product but to determine how hard the effort still has to be made to improve quality in the future. When carrying out the Pre Test, there were four students who were absent from a total of 32 students in class X MIPA 1. However, in the post test all students attended so that students who took the post test were 32 people. Because there are differences in the number of students who take the post test and pre test.

\section{b. Assessment of the efficiency of teaching materials}

In this development research E-learning teaching materials are considered to have high efficiency, some of the reasons the teaching materials are considered to have high efficiency include: 
1. E-learning teaching materials can be used to study at school or study independently at home.

2. Practical to carry anywhere.

3. Study anywhere and anytime.

4. The lack of lesson hours in delivering material in class can be anticipated with this E-learning teaching material.

5. E-learning teaching materials enrich existing learning resources.

c. Assessment of the attractiveness of teaching materials

From online questionnaires distributed to students with the question whether you are interested in E-learning teaching materials, those who answered yes there were $100 \%$ and only $0 \%$ or no one answered no.

\section{Product Revision}

In product revision stage 2 , revisions were made based on student input in one one trial and small group trials. Enter it is the color reminded and the cover design is replaced with the theme of learning PPKn with E-learning teaching materials. With the results of the last product revision, it is expected to increase the attractiveness of E-learning teaching materials and increase effectiveness when used for learning PPkn.

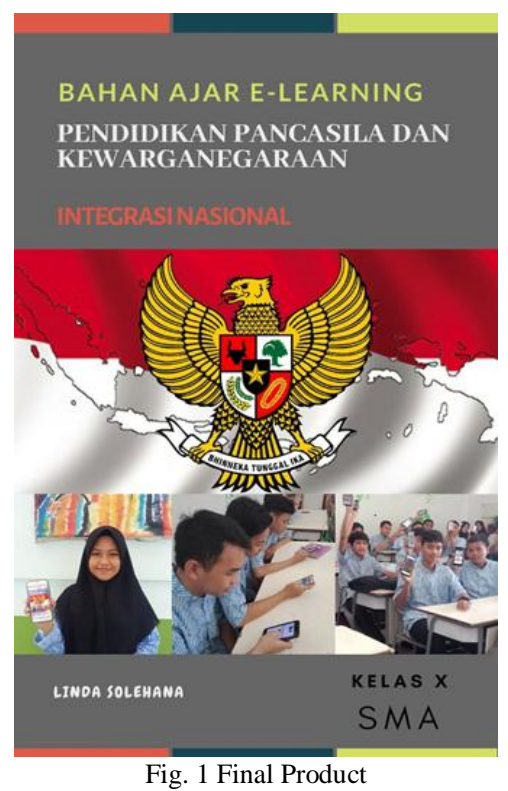

\section{Improvement of Teaching Materials}

The stages that have been completed by the researcher make it possible for E-learning teaching materials to be used as learning resources in the classroom and as a source of independent learning for students. There is no perfect word in every product test. Included in the development of Edmodobased teaching materials in this class X SMA National Integration KD.

\section{B. Discussion}

In developing the Learning Materials of E-learning Based on Edmodo on the KD Integration National Class X High School based on the characteristics of the Pancasila and
Citizenship Education lesson (PPKn), where PPKn subjects who have a vision and mission develop students become human beings who have a sense of nationality and love of the land learning water can be done in a network (virtual) using the PPKn learning strategy that leads to the achievement of competencies that have been designed in curriculum documents.

The strategies applied certainly adhere to several principles, including: first being student-centered, secondly developing students' creativity, thirdly creating pleasant and challenging conditions, all four with values, ethics, aesthetics, logic, and kinesthetic, and fifth providing diverse learning experiences through the application of various strategies and methods of learning that are fun, contextual, effective, efficient, and meaningful (Tolib and Nuryadi, 2017: 23).

The learning strategies mentioned above can be realized in a scientific process-based learning approach. The scientific approach can use several learning models including utilizing Information and Communication Technology (ICT) (Tolib and Nuryadi, 2017: 32). The use of ICT in ordinary learning occurs through the development of Edmodo-based E-learning Teaching Materials.

Understanding E-learning has a very broad meaning and is still perceived differently. In Suartama and Kade Tastra (2014: 11), Rosenberg (2001) defines E-learning as the use of internet technology to distribute subject matter, so students students can access from anywhere. In this study researchers used the definition of E-learning proposed by Rosenberg (2001), that what is meant by E-learning is as the use of internet technology to distribute subject matter, so students can access from anywhere. E-Learning was chosen by researchers because E-learning is able to improve efficiency, effectiveness, transparency, accountability, and convenience of learning so that learning services are better, interesting, interactive and attractive.

In this development research researchers used the Blended learning learning model proposed by Darmawan, namely conventional learning by utilizing e-lerning teaching materials.

Through this model, learning will be more varied where learning that is generally done face to face will be assisted with E-learning that is online by using information technology.

The researcher chose to develop teaching materials, based on the benefits that would be felt if the teaching material was made by the teacher concerned. namely, first, the availability of teaching materials that match the characteristics and settings or social environment of students. Second, help students in obtaining alternative teaching materials in addition to text books that are difficult to obtain. Third, facilitate teachers in carrying out learning (Daryanto and Dwi, 2014: 171).

From the opinions of Daryanto and Dwi about the benefits of teaching materials as mentioned above, it can be concluded that E-learning teaching materials with the Blended learning learning model can be developed in this study. The things that form the basis of its development are 
the E-learning teaching materials of students not dependent on textbooks that are difficult to obtain and the limited number can be overcome.

In this study the reference design of the media developed refers to the Self-paced learning approach. The self-paced learning approach that the research uses in this study is Online resources links. Online resources links are in accordance with the folder menu in Edmodo developed. the links contained in Online resources links can be used to access online learning resources such as handouts, videos, simulations, links related to learning material.

Learning Management System (LMS), who chose this study was Edmodo. Edmodo is a medium for carrying out online learning, which combines some features of the Learning Management System (LMS) and some features of the Social Network.

The choice of Edmodo is based on Edmodo's strengths, namely: first, the ease of sending files, images, videos and links. Second, send individual messages to the instructor. Third, Make a group for discussion. Fourth, a safe environment for new students, Fifth, messages are designed to be more easily understood and not limited by the number of characters.

In this study researchers used constructivism theory. Constructivism Theory is relevant learning theory and supports the implementation of E-learning (Darmawan, 2014: 51-59).

With constructivism theory, students are directly and actively involved in thinking problems, finding ideas and decisions, developing new knowledge, applying them in all situations, so they will remember all concepts longer.

The final goal of this research is that there is a change in students' behaviour towards better direction. Learning behaviour cannot be separated from learning actions because of the signs that students have learned something change in behaviour on him. Behaviour changes in the form of changes that are knowledge (cognitive) and psychomotor skills and values and attitudes (affective) (Siregar and Nara in Dirman and Juarsih, 2014: 4).

\section{CONCLUSIONS}

Based on the development of Edmodo-based E-learning materials with material on national integration has been revised. The revised aspects and improvements are based on the analysis of the trial data that has been carried out and to explore some of the common aspects in this product are:

1. Accuracy of teaching materials, media design and learning design.

2. Quality of display and presentation of material on the product

3. The effectiveness and efficiency of teaching materials

4. Victory of teaching materials

Using the above aspects, the development of Edmodobased E-learning teaching materials on the material for class $\mathrm{X}$ SMA national integration can be summarized as follows:

1. Edmodo-based E-learning materials are seen as effective in achieving the learning objectives of PPKn.
2. Edmodo-based E-learning teaching materials have a high time and place efficiency with regard to the limitations of available teaching materials.

3. Learning materials based on Edmodo are strategies for delivering messages that have high competitiveness.

4. Noting the validation of the experts and the results of trials in the field, it can be concluded that the E-learning materials based on Edmodo on the national integration material are suitable for use in the PPKn Class X High School

To find out student learning behaviour, observations were carried out by researchers by involving fellow PPKn teachers. Process by using observation sheets. The results of observations of student learning behaviour are as follows:

1. That students like to learn by using the blended learning learning model in classical learning activities.

2. Active students ask the teacher if there is material that is difficult to understand.

3. Students work on practice questions diligently.

4. Students will look for answers to questions that have not been known to answer with E-learning teaching materials.

5. Students study hard and try to get high scores in doing the exercises after learning with E-learning teaching materials.

6. Students are happy to learn PPKn with Edmodo.

7. E-learning teaching materials look more attractive than student worksheets (LKS).

8. Material of Edmodo-based elearning teaching materials aroused the interest of students to learn it.

9. Students discuss the material contained in Edmodo-based E-learning teaching materials with their friends

10. To add learning resources students also learn material about national integration besides those in Edmodo.

11. Students are active in learning activities using Edmodobased E-learning teaching materials.

12. Students record and summarize the things that are important in learning activities using E-learning teaching materials

13. Students are very enthusiastic and active in using Edmodo-based E-learning teaching materials according to the instructions.

\section{REFERENCES}

Asrori, M. \& Ali, M. (2014). Metodelogi dan Aplikasi: Riset Pendidikan. Jakarta: PT.Bumi Aksara.

Darmawan, Deni. (2014). Pengembangan E-learning Teori dan Desain. Bandung: PT Remaja Rosdakarya.

Daryanto \& Dwi, Cahyono Aris. (2014). Pengembangan Perangkat Pembelajaran (Silabus, RPP,PHB, Bahan Ajar). Yogyakarta: Gava Media.

Dirman \& Juarsih, Cicih. (2014). Teori Belajar dan PrinsipPrinsip Pembelajaran yang mendidik. Jakarta: Rineka Cipta.

Kementerian pendidikan dan Kebudayaan. (2017). Model Silabus Mata Pelajaran Sekolah Menengah Atas/Madrasah Aliyah Kejuruan (SMA/MA/SMK/MAK): Mata Pelajaran Pendidikan Pancasila dan Kewarganegaraan (PPKn). Jakarta. 
Solihatin, Etin. (2012). Strategi Pembelajaran PPKn. Jakarta: Bumi Aksara.

Suartama, I Kadek \& Kade Tastra, I Dewa. (2014). Elearning Berbasis Moodle. Singaraja: Graha Ilmu.

Tolib \& Nuryadi. (2017). Buku Guru, Pendidikan Pancasila dan Kewarganegaraan. Jakarta: Pusat Kurikulum dan Perbukuan, Balitbang, Kemendikbud. 